\section{Kidney \\ Blood Pressure \\ Research}

\title{
Protective Effect of Dexpanthenol on Ischemia-Reperfusion-Induced Renal Injury in Rats
}

\author{
Ramazan Altintas $^{\mathrm{a}} \quad$ Hakan Parlakpinar ${ }^{\mathrm{b}} \quad$ Ali Beytur $^{\mathrm{a}} \quad$ Nigar Vardic $^{\mathrm{c}}$ \\ Alaadin Polat ${ }^{d}$ Mustafa Sagir ${ }^{b}$ Gul Pelin Odabas ${ }^{\mathrm{e}}$ \\ aDepartment of Urology, Medical Faculty, Inonu University, Malatya, Turkey, ${ }^{b}$ Department of \\ Pharmacology, Medical Faculty, Inonu University, Malatya, Turkey, 'Department of Embriology and \\ Histology, Medical Faculty, Inonu University, Malatya, Turkey, ${ }^{\mathrm{D}}$ Department of Physiology, Medical \\ Faculty, Inonu University, Malatya, Turkey, eUnder-graduated student, Medical Faculty, Inonu University, \\ Malatya, Turkey
}

\author{
Key Words \\ Dexpanthenol Ischemia-reperfusion $\cdot$ Kidney $\bullet$ Oxidative stress $\cdot$ Rat
}

\begin{abstract}
Background/Aims: This experimental study was designed to investigate protective and therapeutic effects of Dexpanthenol (Dxp), an alcoholic analogue of pantothenic acid, on kidney damage induced by ischemia-reperfusion (I/R) in rats. Methods: Forty rats were randomly divided into a control group and $4 \mathrm{I} / \mathrm{R}$ groups ( $1 \mathrm{~h}$ ischemia followed by $23 \mathrm{~h}$ reperfusion). Three I/R groups were treated by $\operatorname{Dxp}(500 \mathrm{mg} / \mathrm{kg}$, i.p.) at 3 different time points (before ischemia, during ischemia and late reperfusion). The histopathological findings including apoptotic changes, and also tissue malondialdehyde (MDA), superoxide dismutase (SOD), catalase (CAT), glutathione peroxidase (GPX), blood urea nitrogen (BUN), serum creatinine ( $\mathrm{Cr}$ ) and albumin (Alb) levels were determined. Results: Kidney tissue MDA levels were found to be significantly higher in the I/R group, whereas the values of GPX were lower when compared to the control group. The levels of SOD and CAT did not reach to statistical meaning level in I/R group. Dxp given during ischemia reduced the elevated MDA levels to the nearly control levels and this ameliorating effect was found as parallel to the result of GPX. Serum levels of $\mathrm{BUN}$ and $\mathrm{Cr}$ were significantly higher in I/R group. Dxp given during ischemia significantly reduced the elevated BUN and $\mathrm{Cr}$ levels when compared to I/R group. Renal I/R injury also induced extensive tubular necrosis, glomerular damage and apoptosis in the histological evaluation. Dxp ameliorated these histological damages in different amounts in all treatment groups. Conclusion: In this study the protective effects of Dxp against renal I/R injury has been evaluated for the first time.
\end{abstract}




\section{Kidney Blood Pressure Research}

Kidney Blood Press Res 2012;36:220-230

\begin{tabular}{l|l}
\hline DOI: $10.1159 / 000343411$ & (c) 2012 S. Karger AG, Basel
\end{tabular}

Published online: November 15, 2012

www.karger.com/kbr

Altintas/Parlakpinar/Beytur et al.: Renal Ichemia-Reperfusion and Dexpanthenol Injury

\section{Introduction}

Many conditions; such as sepsis, shock, hydronephrosis, open renal stone surgery, partial nephrectomy, renal transplantation and renal artery's revascularization, may cause ischemic injury in the kidneys [1-4]. The term ischemia refers to a lack of blood flow, which leads to insufficient oxygen and nutrient supply to tissue, resulting in tissue damage. Although the restoration of blood flow, called reperfusion, is the only way to save the kidney tissue from eventual necrosis, it often exacerbates renal dysfunction, including inflammatory cell infiltration, production of oxygen-derived reactive oxygen species (ROS) and microvascular damage. After the reperfusion of ischemic tissue, ROS - a main cause of reperfusion injurycan form. Paradoxically, the reperfusion of ischemic tissue leads to more severe damage than the ischemic injury itself. A number of studies have been conducted regarding the role of ROS and the inflammatory process in the pathophysiology of renal ischemia-reperfusion (I/R) injury [5-7].

In contrast to oxidative stress, which occurs immediately after reperfusion, the inflammatory response can last a long time and cause irreversible tissue damage [8-10]. All of these hazardous events can lead to undesirable conditions, including hypertension and renal failure [11]. Although, several antioxidants and anti-inflammatory agents have been used to prevent or decrease the kidney damage that can be caused by I/R injury [12-15], there have been no studies on the protective and therapeutic effects of dexpanthenol (Dxp) against renal I/R injury.

Dexpanthenol (D-panthenol; (+)-2,4-dihydroxy-N-(3-hydroxypropyl)-3,3 dimethylbutyramide) (Dxp), an alcoholic analogue of pantothenic acid (PA), is oxidized to PA within tissues [16]. It is well established that PA and its derivatives increase the level of reduced glutathione (GSH), Coenzyme A (Co A) (especially mitochondrial Co A) and adenosine-5'triphosphate (ATP) synthesis within the cell [17-19]. All of them play a major role in cellular defence and in the repair systems against oxidative stress and the inflammatory response $[20,21]$.

This experimental study was designed to investigate the protective and therapeutic effects of Dxp on kidney damage induced by I/R in an in vivo rat model. To examine these effects, we evaluated histopathological findings, including apoptotic changes; biochemical analyses were performed for the determination of tissue malondialdehyde (MDA), superoxide dismutase (SOD), catalase (CAT), glutathione peroxidase (GPX), blood urea nitrogen (BUN), serum creatinine $(\mathrm{Cr})$ and albumin (Alb) levels.

\section{Materials and Methods}

Animals and Experimental Protocol

The experimental protocol in our study was approved by the Ethical Committee on Animal Research of Inonu University. The Guidelines for Animal Research from the National Institutes of Health publication were followed for all experimental procedures. Forty male, post-pubertal (10-12 weeks) Wistar Albino rats, weighing 250-300 g, were obtained from Inonu University Laboratory Animals Research Center and maintained in a temperature- $\left(21 \pm 2^{\circ} \mathrm{C}\right)$, humidity- $(60 \pm 5 \%)$ and light- $(12$ : 12 -h light and dark cycle) controlled room on a standard commercial pellet diet and water ad libitum.

The rats were randomly divided into 5 groups $(n=8)$ as follows: group 1 - control, only underwent right nephrectomy; group 2 - I/R; group 3 - $500 \mathrm{mg} / \mathrm{kg}$ Dxp (Bepanthene ampul ${ }^{\circledR}, 500 \mathrm{mg}$, Bayer Corp., Istanbul, Turkey) given intraperitoneally (i.p.) $30 \mathrm{~min}$ before ischemia; group 4 - $500 \mathrm{mg} / \mathrm{kg}$ Dxp given i.p. $30 \mathrm{~min}$ before the end of reperfusion; and group 5 - $500 \mathrm{mg} / \mathrm{kg}$ Dxp given i.p. $30 \mathrm{~min}$ after the beginning of ischemia (Fig. 1). The dosage of Dxp was chosen according to previous dose-response studies [22, 23].

\section{Surgical Procedure}

Ketamine $(70 \mathrm{mg} / \mathrm{kg}$ ) and xylazine $(8 \mathrm{mg} / \mathrm{kg})$ were used to anaesthetize the animals before the procedure. The surgeons were blinded to the treatment groups. Each animal's lumbar area was shaved 


\section{Kidney Blood Pressure Research}

Kidney Blood Press Res 2012;36:220-230

\begin{tabular}{l|l}
\hline DOI: $10.1159 / 000343411$ & (c) 2012 S. Karger AG, Basel
\end{tabular}

Published online: November 15, 2012

www.karger.com/kbr
Fig. 1. Schematic Representation of Timing of Ischemia, Reperfusion and Administration of Dexpanthenol in experimental groups. I: Ischemic period, R: Reperfusion period, *: Administration time of Dexpanthenol, h: Hour.

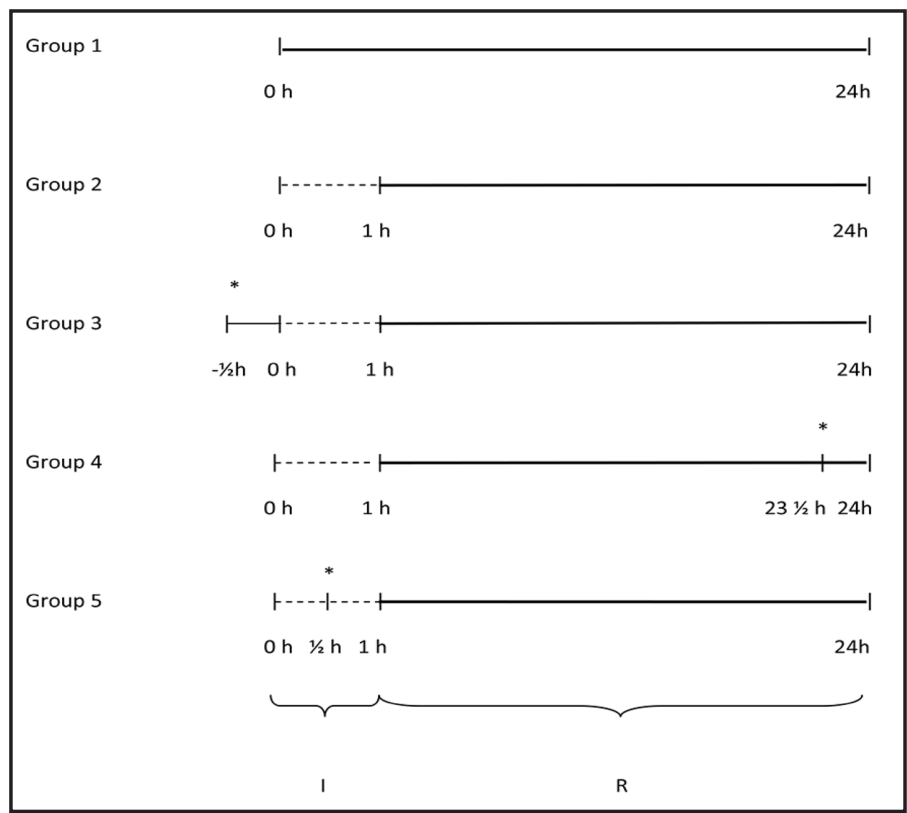

with electric clippers and then prepared with povidone-iodine (Poviiodeks ${ }^{\circledR}$, Kim-Pa Corporation, Istanbul, Turkey). During the surgical procedures, aseptic conditions were maintained in a local sterile environment. Following preparation of the surgical area, midline laparotomies were carried out and right nephrectomies were performed on all animals in all groups. After the right nephrectomies, no further surgical procedures were performed for $30 \mathrm{~min}$ to allow for circulatory adjustment. Then, the left renal artery and vein were occluded together by an atraumatic clamp for $60 \mathrm{~min}$. Following $60 \mathrm{~min}$ of ischemia, a reperfusion period was started by removing the clamp. Re-initiation of pulsation through the vessel was confirmed visually. After controlling the bleeding, the skin and skin textures were sutured again. After $24 \mathrm{~h}$, the animals were sacrificed with high doses of the anaesthesia mixture, and the kidneys were quickly removed, decapsulated, and divided equally into two longitudinal sections. One of these sections was placed in formaldehyde solution for routine histopathological examination by light microscopy. The other half of the kidney was placed in liquid nitrogen and stored at $-70{ }^{\circ} \mathrm{C}$ until assayed for MDA, SOD, CAT and GPX. Trunk blood was extracted to evaluate serum levels of BUN, $\mathrm{Cr}$ and Alb using an Olympus Autoanalyzer (Olympus Instruments, Tokyo, Japan).

\section{Biochemical Analyses}

Determination of MDA. The MDA contents of the homogenates were determined spectrophotometrically by measuring the presence of thiobarbituric acid reactive substances [24]. Three ml of $1 \%$ phosphoric acid and $1 \mathrm{ml} 0.6 \%$ thiobarbituric acid solution were added to $0.5 \mathrm{ml}$ of homogenate pipetted into a tube. The mixture was heated in boiling water for $45 \mathrm{~min}$. After the mixture cooled, the coloured part was extracted into $4 \mathrm{ml}$ of $n$-butanol. The absorbance was measured by spectrophotometer (UV-1601; Shimadzu, Kyoto, Japan) at 532 and $520 \mathrm{~nm}$. The amount of lipid peroxides was calculated as thiobarbituric acid reactive substances of lipid peroxidation. The results were expressed in $\mathrm{nmol} / \mathrm{g}$ tissue, according to a prepared standard graph.

Determination of SOD activity. Total SOD activity was determined according to the method of Sun et al. [25]. The principle of the method is the inhibition of nitroblue tetrazolium (NBT) reduction by the xanthinexanthine oxidase system as a superoxide generator. One unit of SOD was defined as the amount of enzyme causing 50\% inhibition in the NBT reduction rate. SOD activity was expressed in U/g protein.

Determination of CAT activity. CAT activity was determined according to a method developed by Aebi [26]. The principle of the assay is based on the determination of the rate constant $\left(k, \mathrm{~s}^{-1}\right)$ or the $\mathrm{H}_{2} \mathrm{O}_{2}$ decomposition rate at $240 \mathrm{~nm}$. Results were expressed as $\mathrm{k} / \mathrm{g}$ protein.

Determination of GPX activity. GPX activity was measured by the method of Paglia and Valentine [27]. An enzymatic reaction in a tube containing NADPH, reduced glutathione (GSH), sodium azide and 


\section{Kidney \\ Blood Pressure Research}

glutathione reductase was initiated by adding $\mathrm{H}_{2} \mathrm{O}_{2}$; the change in absorbance at $340 \mathrm{~nm}$ was observed using a spectrophotometer. Activity was expressed as $\mathrm{U} / \mathrm{mg}$ protein.

\section{Histological Analyses}

The kidney tissues were fixed in a 10\% formalin solution, and then embedded in paraffin. The $5 \mu$ cut sections were stained with haematoxylin and eosin (H\&E). For immunohistochemical analyses, thick sections were mounted on polylysine-coated slides. After rehydrating, the samples were transferred to citrate buffer ( $\mathrm{pH} 7.6)$ and heated in a microwave oven at $65^{\circ} \mathrm{C}$ for $20 \mathrm{~min}$. After cooling for $20 \mathrm{~min}$ at room temperature, the sections were washed with phosphate buffered saline (PBS). Then the sections were kept in $0.3 \% \mathrm{H}_{2} \mathrm{O}_{2}$ for $7 \mathrm{~min}$, followed by a wash with PBS. Subsequently, the sections were incubated with primary rabbit-polyclonal cysteine aspartate specific proteinase (caspase-3) (Neomarker, USA), rinsed in PBS and then incubated with biotinylated goat anti-polyvalent for $10 \mathrm{~min}$ and streptavidin peroxidase for $10 \mathrm{~min}$ at room temperature. The staining procedure was completed with chromogen+substrate for $15 \mathrm{~min}$ and the slides were counter-stained with Mayer's haematoxylin for one min. Caspase-3 was used according to the manufacturer's instructions with a minor revision. The histological kidney tissue slides were semiquantitatively evaluated and graded as follows: 0 , normal; I, areas of tubular epithelial cell necrosis and desquamation involving < $25 \%$ of cortical tubules; II, similar changes involving $25-50 \%$ of cortical tubules; III, similar changes involving $50-75 \%$ of cortical tubules; and IV, similar changes involving $>75 \%$ of cortical tubules.

\section{Semi-quantitative Evaluation}

The tissue sections were evaluated for the presence of tubular necrosis and apoptosis. Tubular necrosis areas (the areas full of necrotic tubular epithelial cells) were measured in ten different fields using the Leica Q Win Image Analysis System (Leica Micros Imaging Solution Ltd., Cambridge, UK). Caspase-3 staining was also evaluated semi-quantitatively as weak, moderate and strong according to the intensity of staining and quantity of stained tubules. Stained tubules with caspase- 3 were detected by counting 100 tubules on the slides and were classified into one of the three intensity categories. The sections were examined using a Leica DFC 280 light microscope by an experienced observer unaware of the identity of the animal treatment groups.

\section{Statistical Analysis}

For detecting even minor effects, the required sample sizes used in this experiment were identified using statistical power analysis. The sample sizes necessary for a power of 0.80 were estimated using NCSS software. Data were analysed using the SPSS software program for Windows, version 15.0 (SPSS Inc., Chicago, IL). The normality of the distribution was confirmed using the Kolmogorov-Smirnov test. According to the results obtained from the normality test, one-way analysis of variance (ANOVA) and the KruskalWallis $\mathrm{H}$ test were used for the statistical analysis, as appropriate. Multiple comparisons were carried out by Tamhane's test after the ANOVA test. The results are expressed as mean \pm standard deviation (S.D.). After a significant Kruskal-Wallis H test, a Conover test was also carried out for Alb and Cr. Results were considered statistically significant at $\mathrm{P}<0.05$. The values were given as median (min-max).

\section{Results}

\section{Body and Kidney Weight}

No animals died during or after the injections or surgical procedures. There were no differences between the body weights before and after the experiments among the groups (data not shown). The kidney weights of the I/R rats were significantly higher than those of the control group; treatment with Dxp did not reduce weights to the levels of the control group (Table 1).

\section{Effect of Dxp on Serum Parameters}

As shown in Table 1, briefly, serum levels of BUN and Cr were significantly higher in the I/R group (139 \pm 8.44 and $2.02 \pm 0.24 \mathrm{mg} / \mathrm{dL}$, respectively) when compared to the 


\section{Kidney Blood Pressure Research}

Table 1: The serum levels of BUN, Cr, albumin and renal tissue weights

\begin{tabular}{lcccc}
\hline Group Names & $\begin{array}{c}\text { BUN }(\mathrm{mg} / \mathrm{dL}) \\
\text { Mean+SD }\end{array}$ & $\begin{array}{c}\text { Cr }(\mathrm{mg} / \mathrm{dL}) \\
\text { Mean+SD }\end{array}$ & $\begin{array}{c}\text { Albumin (g/dL) } \\
\text { Median (Min-Max) }\end{array}$ & $\begin{array}{c}\text { Renal Tissue Weight } \\
\text { (g) Median (Min-Max) }\end{array}$ \\
\hline Group 1 & $28,86 \pm 2.23$ & $0.58 \pm 0.02$ & $1.10(0.7-1.1)$ & $0.76(0.65-0.93)$ \\
Group 2 & $139 \pm 8.44^{*}$ & $2.02 \pm 0.24^{*}$ & $0.85(0.7-1.1)$ & $0.94(0.85-1.26)^{*}$ \\
Group 3 & $139.28 \pm 6.50^{*}$ & $2.05 \pm 0.18^{*}$ & $1(0.8-1.2)$ & $1.17(0.74-1.37)^{*}$ \\
Group 4 & $116.57 \pm 16.65^{*}$ & $1.82 \pm 0.29^{*}$ & $1(0.8-1.2)$ & $0.96(0.96-1.61)^{*}$ \\
Group 5 & $97.28 \pm 8.72^{* * * * * * *}$ & $1 \pm 0.09^{*, * * * * * *}$ & $0.7(0.6-0.9)^{*, * * * * * * * *}$ & $0.86(0.8-1)^{*, * * *, * * * *}$ \\
\hline
\end{tabular}

${ }^{*} \mathrm{p}<0.05$ versus Group 1; ${ }^{* *} \mathrm{p}<0.05$ versus Group 2; ${ }^{* * *} \mathrm{p}<0.05$ versus Group $3 ;{ }^{* * * *} \mathrm{p}<0.05$ versus Group 4

control group $(28.86 \pm 2.23$ and $0.58 \pm 0.02$ $\mathrm{mg} / \mathrm{dL}$, respectively). In group 5 (Dxp given 30 min after the beginning of ischemia), the elevated BUN and Cr levels were significantly lower than those in the I/R group. The I/R procedure did not significantly change the levels of Alb when compared to the control group (0.85 (0.7-1.1) g/dL vs. 1.10 (0.7-1.1) $\mathrm{g} / \mathrm{dL}$, respectively).

\section{Effect of Dxp on I/R-Induced Changes in Kidney Tissue Enzymes and Lipid Peroxides}

As shown in Table 2, kidney tissue MDA levels were found to be significantly higher in the I/R group (142 \pm 14 vs. $86 \pm 7 \mathrm{nmol} / \mathrm{g}$ tissue), whereas the values of GPX were lower when compared to the control group (1.57 (1.15-1.97) vs. 2.34 (1.76-3.27) U/mg protein, respectively). Although the levels of SOD and CAT in the I/R group did not reach a statistically meaningful levels when compared to the control group, they were found to have a tendency to decrease when compared to the control group.

In group 5 (Dxp given $30 \mathrm{~min}$ after the beginning of ischemia), the elevated MDA levels were reduced nearly to control levels. This ameliorating effect was found to parallel the GPX result in group 5. Dexpanthenol treatment elevated the levels of SOD, CAT and GPX enzyme activities in group 3 and group 4 when compared to the I/R group. Unfortunately, Dxp treatment did not show a beneficial effect on SOD or CAT activities in group 5 .

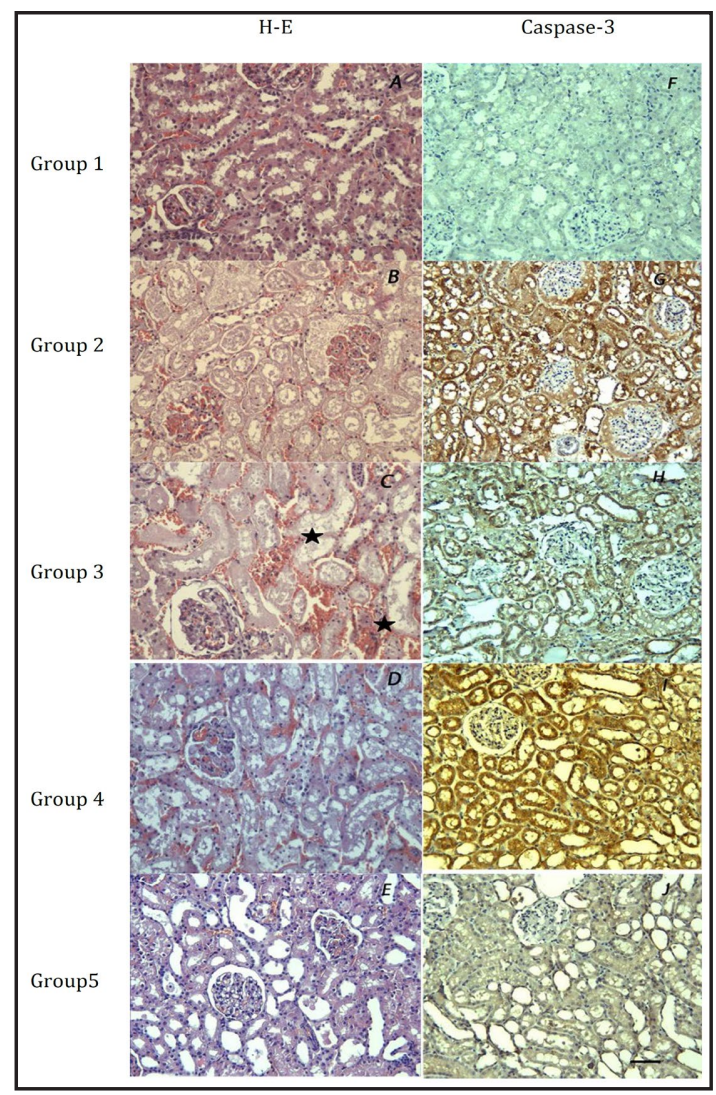

Fig. 2. Histological photographs of kidney tissues from groups: A: normal glomeruli and tubules; B: extensive tubular necrosis (stars); C and D: market renal damage; E: similar histological appearance with group 1 except tubular epithelial desquamation seen. F: no Caspase-3 positive cells; G: market Caspase-3 staining; H: much less Caspase- 3 staining; I: similar Caspase-3 staining with group 2; J: weak Caspase- 3 staining (X 20). The size bar is $50 \mu \mathrm{m}$.

\section{Histological Results}

There were no histological alteratio-ns in group 1 (Fig. 2A). On the other hand, group 2 had extensive tubular necrosis, mainly located at the proximal tubules. In addition, some of the glomeruli were damaged. Dilatation of glomerular capillaries, congestion and enlargement of Bowman's space were observed in the affected glomeruli (Fig. 2B). The tubular necrosis area was decreased in groups 3 (Fig. 2C) and 4 (Fig. 2D) and it was not as extensive as in 


\section{Kidney \\ Blood Pressure Research}

Table 2: The levels of MDA, SOD, CAT and GPx in tissue

\begin{tabular}{|c|c|c|c|c|}
\hline $\begin{array}{l}\text { Group } \\
\text { names }\end{array}$ & $\begin{array}{c}\text { MDA } \\
\text { (nmol/g tissue) } \\
\text { Mean } \pm \text { SD }\end{array}$ & $\begin{array}{c}\text { SOD } \\
\text { (U/g prot) } \\
\text { Median(Min-Max) }\end{array}$ & $\begin{array}{c}\text { CAT } \\
\text { (k/g prot) } \\
\text { Median(Min-Max) }\end{array}$ & $\begin{array}{c}\text { GPX } \\
\text { (U/mg prot) } \\
\text { Median(Min-Max) }\end{array}$ \\
\hline Group1 & $86 \pm 7$ & $0.96(0.93-0.98)$ & $143(126-176)$ & $2.34(1.76-3.27)$ \\
\hline Group 2 & $142 \pm 14^{*}$ & $0.84(0.65-1.06)$ & $134(85-141)$ & $1.57(1.15-1.97)^{*}$ \\
\hline Group 3 & $126 \pm 20^{*}$ & $1.05(0.87-1.29)^{* *}$ & $160(140-185)^{* *}$ & $2.01(1.77-2.33)^{* *}$ \\
\hline Group 4 & $187 \pm 31^{* * * *}$ & $0.53(0.52-0.68)^{* * *, * * *}$ & $82(55-92)^{*, * * * * *}$ & $1.11(1.07-1.55)^{*, * *, * * *}$ \\
\hline Group 5 & $101 \pm 20^{* * * * * * *}$ & $0.91(0.61-1.26)^{* * * *}$ & $138(105-188)^{* * * *}$ & $2.34(2.17-3.29)^{* * * * * *, * * * *}$ \\
\hline $\mathrm{p}$ & $<0.001$ & $<0.001$ & $<0.001$ & $<0.001$ \\
\hline
\end{tabular}

Table 3: The dissociation of histological grades and semi-quantitative analysis of kidney damage with ratios

\begin{tabular}{ccccccc}
\hline Groups & $\mathrm{n}$ & \multicolumn{5}{c}{ Histological Grades } \\
\cline { 3 - 7 } & & 0 & $\mathrm{I}$ & $\mathrm{II}$ & III & IV \\
\hline Group 1 & 8 & $8(100 \%)$ & 0 & 0 & 0 & 0 \\
Group 2 & 8 & 0 & 0 & 0 & $2(25 \%)$ & $6(75 \%)$ \\
Group 3 & 8 & 0 & $3(37.5 \%)$ & $2(25 \%)$ & $1(12.5 \%)$ & $2(25 \%)$ \\
Group 4 & 8 & 0 & $1(12.5 \%)$ & $1(12.5 \%)$ & $3(37.5 \%)$ & $3(37.5 \%)$ \\
\hline Group 5 & 8 & $6(75 \%)$ & $2(25 \%)$ & 0 & 0 & 0 \\
\hline
\end{tabular}

Table 4: Morphometric Analysis of Renal Tubular Necrosis in The Experimental groups

\begin{tabular}{lc}
\hline Group Names & $\begin{array}{c}\text { Necrosis Area }\left(\mu \mathrm{m}^{2}\right) \\
\text { Median (Min-Max) }\end{array}$ \\
\hline Group 1 & $0.0(0.0-0.0)$ \\
Group 2 & $1.702 .330(322.044-8.595 .517)^{*}$ \\
Group 3 & $893.329(0.0-2.959 .626)^{*, * *}$ \\
Group 4 & $1.292 .235(134.015-4.508 .714)^{*}$ \\
Group 5 & $0.0(0.0-200.873)^{* *}$ \\
\hline
\end{tabular}

*Significantly increased when compared with group 1 , ( $\mathrm{P}=0.0007),{ }^{* *}$ Significantly decreased when compared with group $2,(\mathrm{P}=0.0007)$

group 2. However, the difference was not found to be statistically significant between group 2 and these groups. On the other hand, the degree of reduction in the areas of tubular necrosis was more obvious in group 5 than in groups 3 and 4 . The histological appearance of group 5 was similar to group 1, except for mild tubular epithelial desquamation (Fig. 2E). Interstitial congestion and haemorrhage were present in groups 2, 3 and 4.

Caspase-3 examination revealed no apoptotic cells in group 1 (Fig. 2F). However, in group 2, caspase-3 positive cells were found to be significantly increased when compared with group 1 (Fig. 2G). Treatment was found to be more effective in preventing apoptosis in group 3 (Fig. 2H) than in group 4 (Fig. 2I). On the other hand, Dxp administration in group 5 significantly reduced the expression of apoptotic cells (Fig. 2J). The colour density and the number of caspase- 3 stained tubular cells were lower in group 5 than in groups 3 and 4. The results of the morphometric analysis of renal tubular necrosis and semi-quantitative histological examination after staining with caspase-3 are shown with ratios in Table 3-5.

\section{Discussion}

Renal I/R injury causes both intracellular injury and inflammatory reactions, which are related to each other. Aerobic cells, which need oxygen to supply energy, are affected by this injury, and organ failure, especially heart, brain, liver and kidney, can be induced by 


\section{Kidney Blood Pressure Research}

Table 5: Number of Tubules Staining with Caspase-3 in Renal Cortex

\begin{tabular}{lclccl}
\hline $\begin{array}{l}\text { Intensity of } \\
\text { caspase-3 staining }\end{array}$ & \multicolumn{1}{l}{ Group 1 } & \multicolumn{1}{c}{ Group 2 } & \multicolumn{1}{l}{ Group 3 } & Group 4 & Group 5 \\
\hline Absent & $99.0(99.0-100.0)$ & $0.0(0.0-0.0)$ & $0.0(0.0-0.0)$ & $0.0(0.0-0.0)$ & $75.0(49.0-0.0)$ \\
Weak & $1.0(0.0-1.0)$ & $6.0(4.0-50.0)$ & $30.0(29.0-35.0)$ & $10.0(3.0-12.0)$ & $21.0(0.0-45.0)$ \\
Moderate & $0.0(0.0-0.0)$ & $30.0(25.0-35.0)^{*}$ & $16.0(14.0-20.0)^{*}$ & $17.0(15-0-20.0)^{*}$ & $11.0(0.0-13.0)^{*}$ \\
Strong & $0.0(0.0-0.0)$ & $65.0(60.0-70.0)$ & $52.0(50.0-56.0)^{* *}$ & $75.0(72.0-79.0)^{* * *}$ & $0.0(0.0-1.0)$ \\
\hline
\end{tabular}

${ }^{*}$ Significantly increased when compared with group $1, \mathrm{p}<0.0001,{ }^{* *}$ Significantly decreased when compared with group $2, \mathrm{p}<0.0001,{ }^{* *}$ Significantly increased when compared with group $3, \mathrm{p}<0.0001$

this harmful cascade [10]. Ischemia of the kidney, the beginning of the injury process, can be caused by sepsis, shock, hypotension [28], hydronephrosis, renal stone surgery, partial nephrectomy, renal transplantation, renal artery revascularization and cardiothoracic surgery [1-4, 29], and can eventually cause acute renal failure. Ischemic injury begins with the reduction of energy production in the mitochondria, so depletion of energy substrates occurs within the cell. Therefore, cellular ion imbalance and an increase of protease and phospholipase activities exist and cause an increase in cell membrane permeability. Depending on the duration of the ischemic injury, a necrotic type of cell death can occur [10].

On the other hand, the tissue also experiences harmful events during the reperfusion period following ischemia. Oxidative stress, due to the overproduction of ROS and a decrease in the antioxidant level, plays a major role in the formation of I/R injury [29-31]. This starts with the maintenance of reperfusion and leads to membrane lipid peroxidation, oxidation of cell proteins, damage to the DNA helix and cell death $[8,10,32]$. The reperfusion period following ischemia also initiates an inflammatory response cascade. The dead cells, which release ROS, and pro- and anti-inflammatory cytokines and endothelial and macrophagelike cells, which are prompted by ionic reactions, can cause this inflammatory response [10]. This response can last a long time and causes irreversible tissue damage [8-10]. Many drugs, which can block the oxidative stress and inflammatory response cascade, have been used to prevent or decrease I/R injury of the kidney in experimental studies [14, 15, 33-37].

It has been demonstrated that the I/R model induced by clamping the renal bed vessels was properly validated in order to evaluate the effects of different drugs in the context of kidney injury. Dexpanthenol, which is oxidized to PA within tissues [38], has antioxidant and anti-inflammatory effects [22] in addition to its cellular repair capability [8]. There are many studies related to the effect of PA and its derivatives in protecting tissue from ROS activities [17-19, 39]. In similar experimental I/R injury studies, Dxp was shown to be effective in protecting testicular tissue after testicular torsion $[23,40]$. In these studies, when administered i.p. after 90 min of torsion, and 30 min before detorsion, Dxp was reported to decrease lipid peroxidation and tissue damage, and protect testicular tissue against atrophy.

In the current study, we demonstrated that renal I/R induced an increase in MDA levels by causing lipid peroxidation; whereas Dxp, when used before the reperfusion period at a dose of $500 \mathrm{mg} / \mathrm{kg}$, decreased MDA values. MDA is an important sign of oxidative stress and increases due to lipid peroxidation, which is one of the harmful consequences of I/R injury [41]. In the renal vascular bed, I/R rapidly results in cellular injury associated with lipid peroxidation. As lipid peroxidation is the main pathway for radical tissue damage, irrespective of the source of free radicals, blocking this pathway appears to be an attractive strategy to protect the kidney from ROS-mediated damage [12]. Although, none of the usage types of Dxp reduced MDA values to control levels, Dxp, given $30 \mathrm{~min}$ after the start of ischemia, caused significant reduction when compared to the I/R group alone.

Pantothenic acid and its derivatives play a part in the disposal of ROS by increasing GSH and the repair of cell membranes and tissue injury by increasing CoA and ATP synthesis, which produce phospholipids and cholesterol in the cell $[8,20,42]$. In addition to many properties within the cell cycle, GSH and GPX are two important components of the protective 


\section{Kidney Blood Pressure Research}

mechanism of the cell against lipid peroxidation and the oxidative stress, both of which occur during I/R injury $[20,43]$. In the current study, renal I/R injury caused a decrease in GPX levels. However, Dxp given before the reperfusion period increased GPX activity. The most dramatic increase was seen when Dxp was used during the ischemic period.

The reduction in levels of SOD and CAT were not statistically significant in the I/R group when compared to the control group. Superoxide dismutase and CAT are the antioxidant enzyme components of the defence mechanism against ROS activities. Increased levels of these enzymes protect the tissue during renal I/R injury [44, 45]. Unfortunately, renal I/R injury induces a reduction in antioxidant enzymes. At the same time, it was shown that ischemia has potency to increase mRNA level of CAT and SOD, whereas, reperfusion decreases mRNA level of CAT. On the other hand, manganese-SOD remains high during reperfusion [46]. Also, the elevation in level of SOD in renal I/R injury was reported in the other studies $[47,48]$. In the literature, it was recently clearly shown that Dxp has free radical scavenger effects and anti-oxidative properties. Based on this relationship, Slyshenkov et al. [19] reported that PA and pantothenol ameliorate enzyme activities (GPX, CAT, malic enzyme, etc.) in liver tissue. In accordance with previous reports, in the Dxp treatment groups, there were increases in the activities of both SOD and CAT when Dxp was used before the reperfusion period (groups 3 and 5). However, the main elevations were seen when Dxp was administered before the ischemic period (group 5), which is in accordance with the known antioxidant function of Dxp. One of the possible explanations for the surprising values in group 4 (Table 2) is the probable presence of Dxp in the renal tissue. However, there was not enough time for the Dxp to be effective, which is why the enzyme levels were low when compared with the other groups. The other possible explanation is that Dxp given in late reperfusion period (group 4) caused an additional consumption of the antioxidants that were utilized and reduced progressively due to I/R injury. However, we need further investigations to understand the real mechanism(s).

Renal I/R caused elevation of BUN and Cr levels in serum when compared to the control group. One of the other important findings of our study was an improvement of serum levels of BUN and Cr with Dxp, especially when it was used during ischemia, before the reperfusion period. However there was no significant amelioration in the other treatment groups. Elevation of serum BUN and Cr levels is a sign of deterioration of glomerular function, which causes kidney failure over time [13]. Recently, it has been reported that for humans, serum $\mathrm{Cr}$, in association with certain other clinical characteristics, may be a more accurate measure of GFR than Cr clearance. This impairment in glomerular function was accompanied by an increase in BUN. Serum Cr concentration is more significant than BUN level in the earlier phases of kidney disease. On the other hand, BUN begins to rise only after a marked renal parenchymal injury occurs. These findings are compatible with the ischemic lesion related to renal damage [49].

According to our findings, which paralleled the histopathological evidence, administration of Dxp abolished certain I/R injury effects, such as the decreased level of GPX or the increased levels of MDA, BUN and Cr. The kidney weights of the I/R rats were significantly higher than those of the control group. Renal I/R injury also induced extensive tubular necrosis, glomerular damage and apoptosis in the histological evaluation. However, Dxp ameliorated this histological damage in varying amounts in all treatment groups (Fig. 2). Many studies have shown that renal I/R injury causes alterations in renal blood flow via microvascular injury and impaired renal vascular reactivity, and as a consequence, infiltration of inflammatory cells, tubular epithelial cell injury, glomerular damage, apoptosis and fibrosis occur [50-56]. In the current study, Dxp given during the ischemic period decreased the area of tubular necrosis and improved the apoptotic changes confirmed by caspase-3 staining. Although I/R injury increased the kidney weights, Dxp administered during ischemia reduced them in the current study. 


\section{Kidney \\ Blood Pressure Research}

\section{Conclusion}

In this study, the beneficial effects of Dxp on renal I/R injury were evaluated for the first time. Dexpanthenol, given at a dose of $500 \mathrm{mg} / \mathrm{kg}$ (i.p.) during the ischemic period, ameliorated the kidney damage that occurred after I/R injury. The beneficial changes in biochemical parameters, including antioxidant status, BUN and Cr levels were also associated with parallel changes in the histopathological appearance of the tissue.

In summary, Dxp, provitamin B5, is cheap, readily available and considered safe. Based on our results, after further clinical and experimental trials, Dxp could be used during the ischemic period and before reperfusion to protect the kidney against many types of $I / R$ injury.

\section{Conflict of Interests}

The authors have no conflicts of interest to disclose.

\section{References}

$\checkmark 1$ Ricardo SD, Diamond JR: The role of macrophages and reactive oxygen species in experimental hydronephrosis. Semin Nephrol 1998;18:612-621.

-2 Matin SF, Novick AC: Renal dysfunction associated with staged bilateral partial nephrectomy: the importance of operative positioning. J Urol 2001;165:880-881.

$\rightarrow 3$ Anaya-Prado R, Toledo-Pereyra LH: The molecular events underlying ischemia-reperfusion injury. Transpl Proc 2002;34:2518-2519.

-4 Landry GJ, Lau IH, Liem T, Mitchell EL, Moneta GL: Adjunctive renal artery revascularization during juxtarenal and suprarenal abdominal aortic aneurysm repairs. Am J Surg 2010;199:641-645.

5 Kennedy SE, Erlich JH: Murine renal ischemia reperfusion injury. Nephrology 2008;13:390-396.

6 Granger DN, Korthuis RJ: Physiological mechanisms of postischemic tissue injury. Annu Rev Physiol 1995;57:311-332.

7 Matsuyama M, Yoshimura R, Akioka K, Okamoto M, Ushigome H, Kadotani Y, Nakatani T, Yoshimura N: Tissue factor antisense oligonucleotides prevent renal ischemia-reperfusion injury. Transplantation 2003;76:786-791.

8 Hayes JD, McLellan LI: Glutathione and glutathionedependent enzymes represent a co-ordinately regulated defence against oxidative stress. Free Radic Res 1999;31:273-300.

-9 Filho DW, Torres MA, Bordin AL, Crezcynski-Pasa TB, Boveris A: Spermatic cord torsion, reactive oxygen and nitrogen species and ischemia-reperfusion injury. Mol Aspects Med 2004;25:199-210.

$>10$ de Groot H, Rauen U: Ischemia-reperfusion injury: processes in pathogenetic networks: a review. Transplant Proc 2007;39:481-484.

-11 Yamamoto S, Hagiwara S, Hidaka S, Shingu C, Goto K, Kashima K, Noguchi T: The antioxidant EPC-K1 attenuates renal ischemiareperfusion injury in a rat model. Am J Nephrol 2011;33:485-490.

12 Sahna E, Parlakpinar H, Ozturk F, Cigremis Y, Acet A: The protective effects of physiological and pharmacological concentrations of melatonin on renal ischemia-reperfusion injury in rats. Urol Res 2003;3:188-193.

13 Sahna E, Parlakpinar H, Cihan O F, Turkoz Y, Acet A: Effects of aminoguanidine against renal ischemiareperfusion injury in rats. Cell Biochem Funct 2006;24:137-141.

14 Hosseini F, Naseri MK, Badavi M, Ghaffari MA, Shahbazian H, Rashidi I: Effect of beta carotene on lipid peroxidation and antioxidant status following renal ischemia/reperfusion injury in rat. Scand J Clin Lab Invest 2010;70:259-263.

15 Kizilgun M, Poyrazoğlu Y, Oztaş Y, Yaman H, Cakir E, Cayci T, Akgul OE, Kurt YG, Yaren H, Kunak ZI, Macit E, Ozkan E, Taslipinar MY, Turker T, Ozcan A: Beneficial effects of N-acetylcysteine and ebselen on renal ischemia/reperfusion injury. Ren Fail 2011;33:512-517. 


\section{Kidney \\ Blood Pressure Research}

-16 Ebner F, Heller A, Rippke F, Tausch I: Topical use of dexpanthenol in skin disorders. Am J Clin Dermatol 2002;3:427-433.

17 Slyshenkov VS, Dymkowska D, Wojtczak L: Pantothenic acid and pantothenol increase biosynthesis of glutathione by boosting cell energetics. FEBS Lett 2004;569:169-172.

18 Slyshenkov VS, Piwocka K, Sikora E, Wojtczak L: Pantothenic acid protects jurkat cells against ultraviolet light-induced apoptosis. Free Radic Biol Med 2001;30:1303-1310.

19 Slyshenkov VS, Omelyanchik SN, Moiseenok AG, Trebukhina RV, Wojtczak L: Pantothenol protects rats against some deleterious effects of gamma radiation. Free Radic Biol Med 1998;24:894-899.

-20 Slyshenkov VS, Rakowska M, Moiseenok AG, Wojtczak L: Pantothenic acid and its derivatives protect Ehrlich ascites tumor cells against lipid peroxidation. Free Radic Biol Med 1995;19:767-772.

-21 Slyshenkov VS, Rakowska M, Wojtczak L: Protective effect of pantothenic acid and related compounds against permeabilization of Ehrlich ascites tumour cells by digitonin. Acta Biochim Pol 1996;43:407-410.

-22 Ceylan H, Yapici S, Tutar E, Ceylan NO, Tarakçığlu M, Demiryurek AT: Protective effects of dexpanthenol and y-27632 on stricture formation in a rat model of caustic esophageal injury. J Surg Res 2011;171:517523.

23 Etensel B, Ozkisacik S, Ozkara E, Karul A, Oztan O, Yazici M, Gürsoy H: Dexpanthenol attenuates lipid peroxidation and testicular damage at experimental ischemia and reperfusion injury. Pediatr Surg Int 2007;23:177-181.

-24 Uchiyama M, Mihara M: Determination of malonaldehyde precursor in tissues by tiobarbituric acid test. Anal Biochem 1978;34:271-278.

25 Sun Y, Oberley L, Li Y: A simple method for clinical assay of superoxide dismutase. Clin Chem 1988;34:497500 .

26 Aebi H: Catalase; in Bergmeyer HU (ed): Methods of Enzymatic Analysis. New York, Academic Press, 1974, pp 673-677.

-27 Paglia DE, Valentine WN: Studies on the quantitative and qualitative characterization of erythrocyte glutathione peroxidase. J Lab Clin Med 1967;70:158-170.

28 Sheridan AM, Bonventre JV: Pathophysiology of ischemic acute renal failure. Contrib Nephrol 2001;132:721.

29 Chatterjee PK: Novel pharmacological approaches to the treatment of renal ischemia-reperfusion injury: A comprehensive review. Naunyn Schmiedebergs Arch Pharmacol 2007;376:1-43.

30 Greene EL, Paller MS: Oxygen free radicals in acute renal failure. Miner Electrolyte Metab 1991;17:124132.

31 Beckman JS, Koppenol WH: Nitric oxide, superoxide, and peroxynitrite: The good, the bad, and ugly. Am J Physiol 1996;271:1424-1437.

-32 Lien YH, Lai LW, Silva AL: Pathogenesis of renal ischemia/ reperfusion injury: lessons from knockout mice. Life Sci 2003;74:543-552.

-33 Alan C, Kocoglu H, Altintas R, Alici B, Resit Ersay A: Protective effect of decorin on acute ischaemiareperfusion injury in the rat kidney. Arch Med Sci 2011;7:211-216.

-34 Beytur A, Binbay M, Sarihan ME, Parlakpinar H, Polat A, Gunaydin MO, Acet A: Dose Dependent Protective Effect of Ivabradine Against Ischemia Reperfusion Induced Renal Injury in Rats. Kidney Blood Press Res 2011;35:114-119.

-35 Xu YF, Liu M, Peng B, Che JP, Zhang HM, Yan Y, Wang GC, Wu YC, Zheng JH: Protective effects of SP600125 on renal ischemia-reperfusion injury in rats. J Surg Res 2011;169:77-84.

36 Karadeniz Cerit K, Karakoyun B, Yuksel M, Ozkan N, Cetinel S, Tolga Dagli E, Yegen BC, Tugtepe H: The antifibrotic drug halofuginone reduces ischemia/reperfusion-induced oxidative renal damage in rats. J Pediatr Urol 2012 Feb (in press, doi: 10.1016/j.jpurol.2012.01.015).

-37 Talab SS, Elmi A, Emami H, Nezami BG, Assa S, Ghasemi M, Tavangar SM, Dehpour Ar: Protective effects of acute lithium preconditioning against renal ischemia/reperfusion injury in rat: role of nitric oxide and cyclooxygenase systems. Eur J Pharmacol 2012;681:94-99.

-38 Ebner F, Heller A, Rippke F, Tausch I: Topical use of dexpanthenol in skin disorders. Am J Clin Dermatol 2002;3:427-433.

39 Wojtczak L, Slyshenkov VS: Protection by pantothenic acid against apoptosis and cell damage by oxygen free radicals—-the role of glutathione. Biofactors 2003;17:61-73. 


\section{Kidney \\ Blood Pressure Research}

Altintas/Parlakpinar/Beytur et al.: Renal Ichemia-Reperfusion and Dexpanthenol Injury

40 Etensel B, Ozkisacik S, Ozkara E, Serbest YA, Oztan O, Yazici M, Gürsoy H: The protective effect of dexpanthenol on testicular atrophy at 60th day following experimental testicular torsion. Pediatr Surg Int 2007;23:271-275.

-41 Ozdemir R, Parlakpinar H, Polat A, Colak C, Ermis N, Acet A: Selective endothelin A (ET A ) receptor antagonist (BQ 123) reduces both myocardial infarct size and oxidant injury. Toxicology 2006;219:142149.

42 Fernandez-Checa JC, Garcia-Ruiz C, Colell A, Morales A, Mari M, Miranda M, Ardite E: Oxidative stress: role of mitochondria and protection by glutathione. Biofactors 1998;8:7-11.

-43 Van Haaften RI, Haenen GR, Evelo CT, Bast A: Effect of vitamin E on glutathione dependent enzymes. Drug Metab Rev 2003;35:215-253.

44 Parlakpinar H, Olmez E, Acet A, Ozturk F, Tasdemir S, Ates B, Gul M, Otlu A: Beneficial effects of apricotfeeding on myocardial ischemia-reperfusion injury in rats. Food Chem Toxicol 2009;49:802-808.

45 Walker EM, Gale GR: Methods of reduction of cisplatin nephrotoxicity. Ann Clin Lab Sci 1981;11:397-410.

-46 Singh I, Gulati S, Orak JK, Singh AK: Expression of antioxidant enzymes in rat kidney during ischemiareperfusion injury. Mol Cell Biochem 1993;125:97-104.

-47 Erdogan H, Fadillioglu E, Yagmurca M, Uçar M, Irmak MK: Protein oxidation and lipid peroxidation after renal ischemia-reperfusion injury: protective effects of erdosteine and N-acetylcysteine. Urol Res 2006;34:41-46.

48 Tenorio-Velázquez VM, Barrera D, Franco M, Tapia E, Hernández-Pando R, Medina-Campos ON, PedrazaChaverri J: Hypothyroidism attenuates protein tyrosine nitration, oxidative stress and renal damage induced by ischemia and reperfusion: effect unrelated to antioxidant enzymes activities. BMC Nephrol 2005;6:1-12.

49 Parlakpinar H, Tasdemir S, Polat A, Bay-Karabulut A, Vardi N, Ucar M, Acet A: Protective role of caffeic acid phenethyl ester (CAPE) on gentamicin-induced acute renal toxicity in rats. Toxicology 2005;207:169-177.

50 Bonventre JV, Weinberg JM: Recent advances in the pathophysiology of ischemic acute renal failure. J Am Soc Nephrol 2003;14:2199-2210.

51 Devarajan P: Update on mechanisms of ischemic acute kidney injury. J Am Soc Nephrol 2006;17:15031520.

52 Padanilam BJ: Cell death induced by acute renal injury: a perspective on the contributions of apoptosis and necrosis. Am J Physiol Renal Physiol 2003;284:608-627.

53 Herrler T, Tischer A, Meyer A, Feiler S, Guba M, Nowak S, Rentsch M, Bartenstein P, Hacker M, Jauch KW: The intrinsic renal compartment syndrome: new perspectives in kidney transplantation. Transplantation 2010;89:40-46.

54 Sutton TA, Fisher CJ, Molitoris BA: Microvascular endothelial injury and dysfunction during ischemic acute renal failure. Kidney Int 2002;62:1539-1549.

55 Vetterlein F, Petho A, Schmidt G: Distribution of capillary blood flow in rat kidney during postischemic renal failure. Am J Physiol 1986;251:510-519.

56 Yamamoto T, Tada T, Brodsky SV, Tanaka H, Noiri E, Kajiya F, Goligorsky MS: Intravital videomicroscopy of peritubular capillaries in renal ischemia. Am J Physiol Renal Physiol 2002;282:1150-1155. 